American Journal of Animal and Veterinary Sciences 6 (1): 59-64, 2011

ISSN 1557-4555

(C) 2011 Science Publications

\title{
The Effect of Rumen Acid Load on Postpartum Performance and Blood Metabolic Responses in Transition Holstein Cows
}

\author{
${ }^{1}$ Sadjad Danesh Mesgaran, ${ }^{1}$ Alireza Vakili, \\ ${ }^{1}$ Alireza Heravi Moosavi and ${ }^{2}$ Ghasem Koolabadi \\ ${ }^{1}$ Department of Animal Science, Faculty of Agriculture, \\ Ferdowsi University of Mashhad, Mashhad, P. O. Box: 91775-1163, Iran \\ ${ }^{2}$ Department of Research, Dasht Co., Nayshabour, Iran
}

\begin{abstract}
Problem statement: The transition period is the most stressful time in the production cycle of a dairy cow because of depressed feed intake, endocrine and metabolic changes at parturition. The aim was to determine the effect of rumen acid load on postpartum performance and metabolic parameters in transition Holstein cows. Approach: The Acidogenicity Values (AV) of the diets were determined using an In-vitro essay. Thirty late pregnant multiparous Holstein cows with the average yielding of $9800 \mathrm{Kg} /$ year were housed. Three weeks before the expected date of calving, cows were randomly assigned to receive either: (a) High $\mathrm{AV}\left(\mathrm{AV}_{11.9}\right)$ diet $(\mathrm{n}=16)$ (b) Low $\mathrm{AV}\left(\mathrm{AV}_{10.7}\right)$ diet $(n=14)$. Blood samples were collected from the coccygeal vein once a week at a consistent time after morning feeding from d 10 till d 42 postpartum and were analysed for Beta Hydroxybutyrate (BHB), Non-Esterified Fatty Acids (NEFAs), glucose and Blood Urea Nitrogen (BUN). Milk samples were collected from each milking once per week and composited for subsequent analysis of milk composition. Results: Overall subsequent milk yield of animals in high AV was higher compared to the other group (41.9 and $37.8 \mathrm{~kg}$ ). Although milk fat percentage of the low AV group was higher than the other group (3.7 and 3.5\%), however there was no significant effect of the diets on milk protein. Plasma NEFA and BHBA was reduced significantly in animals receiving the high AV diet. Although the concentration of glucose was markedly higher in high AV animals, however the BUN concentration was lower compare to the low AV group. Conclusion: The results of the present study demonstrated that high grain prepartum diets have dramatic impact on postpartum performance and blood metabolic parameters.
\end{abstract}

Key words: Volatile Fatty Acids (VFAs), Non-Esterified Fatty Acids (NEFA), Non-fiber Carbohydrate (NFC), transition period, Blood Urea Nitrogen (BUN), subsequent milk yield, plasma glucose, hepatic lipidosis

\section{INTRODUCTION}

The transition period is the most stressful time in the production cycle of a dairy cow because of depressed feed intake, endocrine and metabolic changes at parturition. Suboptimal transition from the lategestation period to lactation can impair production and reproductive performance and cause economic losses (Drackley, 1999; Overton and Waldron, 2004). The degree of fatty acid mobilization before calving, as indicated by plasma Non-Esterified Fatty Acids (NEFA) concentrations, has been positively related to the incidence of dystocia, retained placentas, ketosis, displaced abomasums and mastitis in the peripartum period (Grummer, 1993). One way to offset reduced energy intake associated with feed intake depression is to increase energy density by increasing Non-fiber Carbohydrate (NFC) of the diet. An increase in dietary NFC may lead to greater propionate concentration in the rumen (Batajoo et al., 1994), which may promote insulin secretion (Harmon, 1992). Because insulin is antilipolytic, an increase in dietary NFC might decrease plasma NEFA and reduce hepatic conversion to triglycerides and ketones. Another advantage of increasing NFC content in the prepartum diet is to increase development of rumen papillae and Volatile Fatty Acids (VFAs) capacity absorption from the rumen (Dirksen et al., 1985). Development of rumen papillae is essential to minimize ruminal VFA accumulation, ruminal $\mathrm{pH}$ reduction and the likelihood of acidosis

Corresponding Author: Alireza Vakili, Department of Animal Science, Faculty of Agriculture,

Ferdowsi University of Mashhad, Mashhad, P. O. Box: 91775-1163, Iran 
when NFC is further increased postpartum. However, there is a need to manage the inclusion of NFC diets to avoid reduced performance due to subacute ruminal acidosis and an increased incidence of clinical acidosis and related disorders (Garrett et al., 1999). An in vitro work has assessed and evaluated a new technique (acidogenicity value; AV) for studying the production of acids during rumen fermentation (Wadhwa et al., 2001). It was proposed that the high concentration of starch in wheat grain is a critical point in AV of a dairy cow diet. Moreover, the impact of different close-up dry cow diets on rumen acid load has not been evaluated. The objective of this study was to evaluate the effect of high grain peripartum diet on postpartum blood plasma metabolic parameters and subsequent milk production and composition.

\section{MATERIALS AND METHODS}

Diets and in-vitro trial: Two commercial dairy diets (forage: concentrate as 1:1) containing different concentrations levels of AV were provided (Table 1). The acidogenicity values of the diets were determined using the procedure as described by Danesh Mesgaran et al. (2009) $\left(\mathrm{XI}^{\text {th }}\right.$ International Symposium on Ruminant Physiology, 2009). Briefly, Samples were oven-dried $\left(48 \mathrm{~h}, 68{ }^{\circ} \mathrm{C}\right)$ and ground through a $1-\mathrm{mm}$ screen on a laboratory mill. One-gram (DM) sample were weighed and incubated, in triplicate, with $30 \mathrm{ml}$ of buffered rumen liquor comprising $60 \%$ buffer and $40 \%$ rumen liquor. The buffer was made up at $20 \%$ of the strength of the Tilley-Terry (1963) buffer. Cysteine hydrochloride monohydrate $(0.025 \% \mathrm{wt} / \mathrm{vol})$ was added just prior to incubations. The rumen fluid was collected, $3 \mathrm{~h}$ after morning feeding, from four fistulated sheep that was maintained on lucerne hay and concentrates ( 70 to $30 \%$ in the DM). The incubations were carried out in 100 -ml bottles held in a water bath at $38.7^{\circ} \mathrm{C}$. Samples $(2 \mathrm{ml})$ were withdrawn from bottles after $24 \mathrm{~h}$ and transferred to 2-ml micro tubes containing $50 \mathrm{mg}$ (excess) of $\mathrm{CaCO}_{3}$ powder. The mixture was shaken manually for $5 \mathrm{~s}$ and then centrifuged (4000 rpm for 10 min) before analysis of $\mathrm{Ca}$ content in the supernatant using Atomic Absorption. The AV was calculated as the product of $\mathrm{Ca}$ concentration (from the analysis) and fluid volume $(30 \mathrm{~mL})$ divided by the sample weight.

Animals: Thirty late pregnant multiparous Holstein cows with the average yielding of $9800 \mathrm{Kg} /$ year were housed. Three weeks before the expected date of calving, cows were randomly assigned to receive either: (a) High $\mathrm{AV}\left(\mathrm{AV}_{11.9}\right)$ diet $(\mathrm{n}=16)$ or (b) Low $\mathrm{AV}$ $\left(\mathrm{AV}_{10.7}\right)$ diet $(\mathrm{n}=14)$ and the average dry matter intake was $12.2 \mathrm{Kg} /$ head/day. After calving, animals in each group received the lactation TMR diet (Table 2) which was fed ad libitum. All cows were milked twice daily and yields were recorded at each milking.

Blood and milk sample collection and analysis: Blood samples were collected from the coccygeal vein into vacutainers containing heparin as anticoagulants. They were collected once a week at a consistent time after morning feeding from d 10 till $\mathrm{d}$ 42 postpartum. Blood samples were kept in ice, centrifuged $(1500 \times \mathrm{g}$ for $15 \mathrm{~min})$ and then stored at $-20^{\circ} \mathrm{C}$.

Table 1: Ingredients of the close-up and early lactation TMR experimental diets (\% DM)

\begin{tabular}{|c|c|c|c|c|}
\hline \multirow[b]{3}{*}{ Ingredients } & \multicolumn{2}{|c|}{ Diets } & & \\
\hline & \multicolumn{2}{|l|}{ Close-up } & \multicolumn{2}{|c|}{ Early lactation } \\
\hline & High AV & Low AV & High AV & Low AV \\
\hline Corn silage & 25.5 & 26.5 & 14.91 & 13.86 \\
\hline Alfalfa & 18.4 & 19.1 & 24.50 & 24.00 \\
\hline Wheat straw & 13.5 & 14.0 & - & 0.93 \\
\hline Barley grain & 8.0 & 8.3 & 15.16 & 11.03 \\
\hline Corn grain & 8.0 & 8.3 & 13.83 & 9.20 \\
\hline Wheat grain & 7.4 & 3.8 & - & - \\
\hline Cottonseed & - & - & 6.59 & 8.60 \\
\hline Soybean meal & 4.3 & 4.4 & 9.90 & 9.2 \\
\hline Rapeseed meal & 2.0 & 2.1 & 3.29 & 4.10 \\
\hline Cottonseed meal & 4.7 & 5.1 & 2.65 & 0.93 \\
\hline Wheat bran & 4.3 & 4.4 & 5.26 & 7.33 \\
\hline Sugar beet pulp & - & - & - & 6.66 \\
\hline Fishmeal & - & - & 2.65 & 2.46 \\
\hline Fat supplement & 1.3 & 1.3 & - & 0.60 \\
\hline Anionic salts & 2.3 & 2.4 & - & - \\
\hline Bicarbonate sodium & - & - & 0.53 & 0.49 \\
\hline Vitamin \& Mineral supplement & 0.4 & 0.4 & 0.72 & 0.67 \\
\hline
\end{tabular}

The acidogenicity of the high AV and low AV close-up diets were 11.9 and 10.7, respectively 
American J. Animal \& Vet. Sci., 6 (1): 59-64, 2011

Table 2: Dry matter intake (DMI, $\mathrm{kg} / \mathrm{d})$, milk production $\left(\mathrm{kg} \mathrm{d}^{-1}\right)$ and milk composition $(\mathrm{g} / \mathrm{kg})$ of dairy cows fed close-up diets differing in rumen acid load as high AV (AV11.9) and low AV (AV10.7)

\begin{tabular}{|c|c|c|c|c|c|c|}
\hline Variable & $\mathrm{AV}_{11.9}$ & $\begin{array}{l}\text { Diets } \\
\mathrm{AV}_{10.7}\end{array}$ & SEM & $\begin{array}{l}\text { P-value } \\
\text { Diet (D) }\end{array}$ & Week (W) & $\mathrm{D} \times \mathrm{W}$ \\
\hline DMI & 24.2 & 22.1 & 0.6 & $<0.05$ & $<0.05$ & NS \\
\hline Milk yield & $41.9^{\mathrm{a}}$ & $37.8^{b}$ & 1.1 & $<0.05$ & $<0.05$ & NS \\
\hline Milk fat & $35^{\mathrm{a}}$ & $37^{\mathrm{b}}$ & 1.2 & $<0.05$ & $<0.05$ & NS \\
\hline Milk protein & 30.2 & 30.4 & 1.3 & NS & $<0.05$ & NS \\
\hline
\end{tabular}

These were analysed for BHB, NEFAs, glucose and BUN. Analyses for glucose, NEFA, BHBA and Blood urea nitrogen were performed using commercially available kits on an Auto analyzer (TARGA 3000, Italy; Glucose, Blood urea nitrogen, Biosystem Ltd., Spain; NEFA: FA 115 kit, Randox Laboratories Ltd., Crumlin, UK; BHBA: Ranbut kit, Randox Laboratories Ltd.). Milk samples were collected from each milking once per week and composited for subsequent analysis of milk composition (Micro Scan; FOSS Electric A/s, Denmark).

Statistical analysis: Milk yield and composition and blood metabolites were analyzed using a mixed model (PROC MIXED, SAS Inst. Inc., Cary, NC, 1999) for a completely randomized design with repeated measures using the following model:

$$
\begin{aligned}
& Y=\mu+T i+A(i) j+D k+(T \times D) i k+R i j k \\
& \text { Where: } \\
& \mathrm{Y}=\text { Dependent variable. } \\
& \mathrm{M}=\text { Overall mean. } \\
& \mathrm{T}=\text { Treatment effects. } \\
& \mathrm{A}=\text { Random effects of animal within } \\
& \text { treatments. } \\
& \mathrm{D}=\text { Effects of sampling day or time. } \\
& \mathrm{T} \times \mathrm{D}=\text { Interaction effects of treatment and }
\end{aligned}
$$

\section{RESULTS}

The results of the current study indicate that the overall subsequent milk yield of animals in high AV was higher compared to the other group. Although milk fat percentage of the low AV group was higher, but there was no significant effect of the diets on milk protein. NEFA concentration was significantly affected by treatment and time $\left(\mathrm{P}_{\text {trt }}=0.0008\right.$ and $\left.\mathrm{P}_{\text {time }}<0.0001\right)$. Although the diet significantly affected the postpartum BHBA concentration, but the effect of time was not significant $\quad\left(\mathrm{P}_{\text {trt }}=0.0024\right.$ and $\left.\mathrm{P}_{\text {time }}=0.7504\right)$. Both Glucose and Urea concentrations were affected markedly by treatment, but no significant effect of time was observed $\left(\mathrm{P}_{\text {trt }}=0.0003, \mathrm{P}_{\text {time }}=0.713\right.$ and $\mathrm{P}_{\text {trt }}=$ $0.0273, \mathrm{P}_{\text {time }}=0.1088$, respectively).

\section{DISCUSSION}

Reports in the literature are conflicting as to the beneficial effects of prepartum feeding on subsequent milk production and composition. Some studies have shown that the prepartum diet had a significant effect on milk protein, fat and lactose percentage (Fronk et al., 1980; Lodge et al., 1975). Increased energy (Nocek et al., 1986) in prepartum diets has increased the percentage of milk protein. Most studies, in contrast to the present one, have found that feeding a high energy diet (regardless of energy source) in the late prepartum period does not alter subsequent milk production (Flipot et al., 1988; Johnson and Otterby, 1981; Van Den Top et al., 1995).

As outlined in Fig. 1 and 2, using high NFC diets as a glucogenic precursor resulted in increased plasma glucose and reduced NEFA and BHBA concentration which is in agreement with the previous studies (Butler et al., 2006; Grummer et al., 1994; Studer et al., 1993). Most studies on feeding more glucogenic nutrients have confirmed the observation of a decrease in plasma NEFA and BHBA concentration (Lemosquet et al., 1997; Reist et al., 2003). Santos et al. (2000) were able to improve energy status of cows during early lactation and increase plasma glucose and insulin, by increasing starch fermentability in the rumen through sorghum grain processing. Minor et al. (1998) observed higher milk production and higher plasma glucose and lower NEFA and BHBA concentration in animals fed diets high in NFC compared with animals fed low in NFC. Yang and Baldwin (1973) reported that high proportions of concentrate in the diets of lactating cows depressed the lipolytic response of adipose tissue to epinephrine. Therefore, the reduced NEFA concentrations might have resulted from the antilipolytic effects associated with diets that are high in NFC and stimulate propionate production. Plasma BHBA concentrations were significantly reduced in animals fed diets with high NFC. Propionate is 
antiketogenic (Grummer, 1993) and thus might have limited ketone production in animals fed diets with high NFC; because plasma NEFA concentrations were reduced in these animals, substrate availability might have also limited ketogenesis. It has been widely accepted that fat mobilization in periparturient cows results from a negative energy balance (Grum et al., 1996).

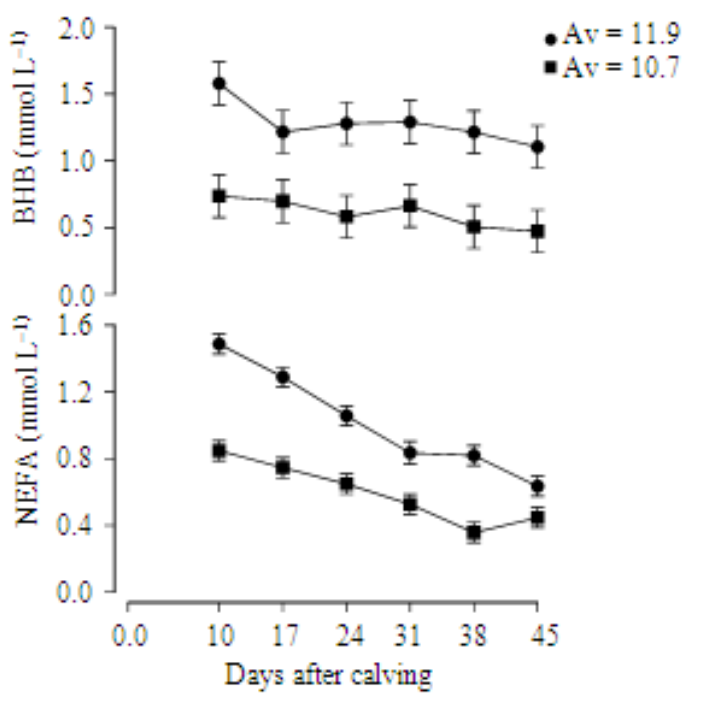

Fig. 1: Plasma NEFA (A) and plasma BHBA (B) concentration for multiparous cows fed high AV $\left(\mathrm{AV}_{11.9}\right)$ or low $\mathrm{AV}\left(\mathrm{AV}_{10.7}\right)$ diet during 10-42 day after calving.

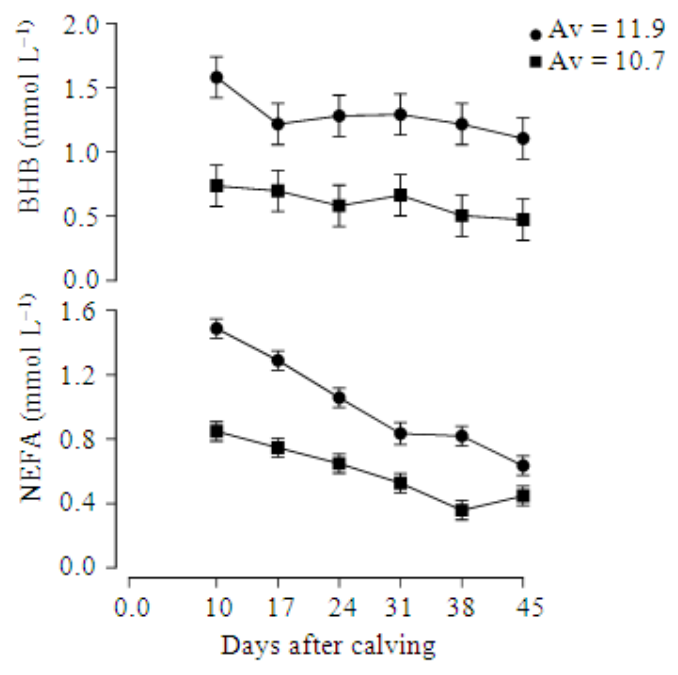

Fig. 2: Graph1. Plasma Glucose (A) and plasma Urea (B) concentration for multiparous cows fed high $\mathrm{AV}\left(\mathrm{AV}_{11.9}\right)$ or low $\mathrm{AV}\left(\mathrm{AV}_{10.7}\right)$ diet during 1042 day after calving.
Bell (1995) estimated that cows at $d 4$ of lactation had a NEFA entry rate of $10.7 \mathrm{~mol} \mathrm{~d}^{-1}$, which is equivalent to $30 \mathrm{Mcal} / \mathrm{d}$. Any living creature is a self-regulating chemical engine, continually adjusting for maximum economy (Nelson and Cox, 1999). The explanation of why the cows mobilized more fat than needed to meet energy requirements may relate to the characteristics of ruminant glucose metabolism. During the periparturient period, the demand for glucose is increased greatly by fetal growth and milk synthesis, at a time when feed intake is depressed. Glycogen content of liver remained low in the first 21 days in milk (DIM) compared with the content at d 19 prior to calving (Vazquez- Anon et al., 1994). The increased milk synthesis, depressed DMI and depletion of liver glycogen suggest that cows could be in a state of glucose deficiency during the periparturient period. Negative energy balance is associated with a decrease in circulating concentrations of insulin, glucose and IGF-I and increased circulating concentrations of NEFA and BHBA (Grummer, 1993). Pushpakumara et al. (2003) suggested that the starch diet was intended to adapt the rumen, enhance papillae development and counter decreases in ME at calving. This in turn should increase insulin and decrease the subsequent NEFA rise, thus resulting in a decreased incidence of metabolic disease. Because elevated hepatic lipid content is associated with an increased incidence of metabolic disorders (Grummer, 1993) feeding high-energy diets prepartum may offer benefits in terms of reducing postparturient disorders. While the effects of prepartum diet, especially the value of added dietary lipid, on hepatic lipidosis needs further research, it seems clear that feeding high grain in the last 2-3 wk before calving should reduce the incidence of hepatic lipidosis.

Results of the current study showed that cows receiving the low AV diet had higher concentration of urea than the high AV group. Elevated plasma urea nitrogen concentrations are indicative of increased ureagenesis, a result of oxidation of amino acids in excess of those required for protein synthesis, or of detoxification of absorbed ammonia (Lobley et al., 2000).

\section{CONCLUSION}

Others have suggested (Grummer, 1993; Drackley, 1999) that nutritional management during the dry period affects susceptibility of cows to metabolic disorders and infectious diseases during the periparturient period. Our study did not have the power (i.e., small number of cows) to address that statement effectively by evaluating incidence of metabolic disorders and infectious diseases. However, our study did provide information regarding the effect of 
prepartum diet on postpartum metabolic status in dairy cattle. Cows fed the high AV diet had a marked decrease in NEFA and BHBA plasma concentration and significant increase in plasma glucose compare to the low AV group. Furthermore, results of the current study indicate that feeding diets high in NFC will result in higher milk yield.

\section{REFERENCES}

Batajoo, K.K. and R.D. Shaver, 1994. Impact of nonfiber carbohydrate on intake, digestion and milk production by dairy cows. J. Dairy Sci., 77: 15801588. DOI: $10.3168 /$ jds.S0022-302(94)77100-9

Bell, A.W., 1995. Regulation of organic nutrient metabolism during transition from late pregnancy to early lactation. J. Anim. Sci., 73:2804-2819. WWW.jas.fass.org/cgi/reprint/73/9/2804.pdf

Butler, S.T., S.H. Pelton and W.R. Butler, 2006. Energy balance, metabolic status and the first postpartum ovarian follicle wave in cows administered propylene glycol. J. Dairy Sci., 89: 2938-2951. DOI:10.3168/jds.S0022-0302 (06)72566-8

Danesh Mesgaran, S., A. Heravi Mousavi, H. JahaniAzizabadi, A. Vakili and F. Tabatabaiee, 2009. The effect of grain sources on in vitro rumen acid load of close-up dry cow diets. Proceedings of the XIth International Symposium on Ruminant Physiology, pp: 146-147.https://colloque.inra.fr/isrp_2009_eng

Dirksen, G.U., H.G. Liebich and E. Mayer, 1985. Adaptive changes of the ruminal mucosa and their functional and clinical significance. Bovine Pract., 20: $116-120$.

Drackley, J.K., 1999. Biology of dairy cows during the transition period: The final frontier. J. Dairy Sci., 82: $\quad 2259-2273 . \quad$ DOI: $\quad 10.3168 /$ jds.S00220302(99)75474-3

Flipot, P.M., G.L. Roy and J.J. Dufour, 1988. Effect of peripartum energy concentration on production performance of holstein cows. J. Dairy Sci., 71: 1840-1850. DOI: $\quad 10.3168 /$ jds.S0022-0302 (88)79753-2

Fronk, T.J., L.H. Schultz and A.R. Hardie, 1980. Effect of dry period overconditioning on subsequent metabolic disorders and performance of dairy cows. J. Dairy Sci., 63: 1080-1090. DOI: 10.3168/jds.S0022-0302 (80)83050-5

Garrett, E.F., M.N. Perreira, K.V. Nordlund, L.E. Armentano and W.J. Goodger et al., 1999. Diagnostic methods for the detection of subacute ruminal acidosis in dairy cows. J. Dairy Sci., 82: 1170-1178. DOI: $\quad 10.3168 /$ jds.S0022-0302 99)75340-3
Grum, D.E., J.K. Drackley, R.S. Younker, D.W. LaCount and J.J. Veenhuizen, 1996. Nutrition during the dry period and hepatic lipid metabolism of periparturient dairy cows. J. Dairy Sci., 79: 1850-1864. DOI: $\quad 10.3168 /$ jds.S0022-0302 (96)76553-0

Grummer, R.R., 1993. Etiology of lipid-related metabolic disorders in periparturient dairy cows. J. Dairy Sci., 76: 3882-3896. DOI: 10.3168/jds.S0022-0302 (93)77729-2

Grummer, R.R., J.C. Winkler, S.J. Bertics and V.A. Studer, 1994. Effect of propylene glycol dosage during feed restriction on metabolites in blood of prepartum holstein heifers. J. Dairy Sci., 77: 36183623. DOI: $10.3168 /$ jds.S0022-0302 (94)77306-9

Harmon, D.L., 1992. Impact of nutrition on pancreatic exocrine and endocrine secretion in ruminants: A review. J. Anim. Sci., 70: 1290-1301. WWW. jas.fass.org/cgi/reprint/70/4/1290.pdf

Johnson, M.M. and D.E. Otterby, 1981. Influence of dry period diet on early postpartum health, feed intake, milk production and reproductive efficiency of holstein cows. J. Dairy Sci., 64: 290-295. DOI: 10.3168/jds.S0022-0302 (81)82566-0

Lemosquet, S., N. Rideau, H. Rulquin, P. Faverdin and J. Simon et al., 1997. Effect of duodenal glucose infusion on the relationship between plasma concentrations of glucose and insulin in dairy cows. J. Dairy Sci., 80: 2854-2865. DOI: $10.3168 /$ jds.S0022-0302 (97)76250-7

Lodge, G.A., L.J. Fisher and J.R. Lessard, 1975. Influence of prepartum feed intake of performance of cows fed ad libitum during lactation. J. Dairy Sci., 58: 696-702. DOI: $10.3168 /$ jds.S0022-0302 (75)84630-3

Minor, D.J., S.L. Trower, B.D. Strang, R.D. Shaver and R.R. Grummer, 1998. Effects of nonfiber carbohydrate and niacin on periparturient metabolic status and lactation of dairy cows. J. Dairy Sci., 81: 189-200. DOI: 10.3168/jds.S00220302 (98)75566-3

Nelson, D.L. and M.M. Cox, 1999. Lehninger Principles of Biochemistry. 3rd Edn., Worth Publisher, New York, NY.www.pdfebooksdownloads.com/Lehninger-AL-Nelson-D-L-Cox-M-"PRINCIPLES-OFBIOCHEMISTRY"-1993.html

Overton, T.R. and M.R. Waldron, 2004. Nutritional management of transition dairy cows: Strategies to optimize metabolic health. J. Dairy Sci., 87: 105119. DOI: $10.3168 /$ jds.S0022-0302 (04)70066-1 
Pushpakumara, P.G., N.H. Gardner, C.K. Reynolds, D.E. Beever and D.C. Wathes, 2003. Relationships between transition period diet, metabolic parameters and fertility in lactating dairy cows. Theriogenology, 60: 1165-1185. DOI: 10.1016/S0093-691X (03)00119-5

Reist, M., D. Erdin, D. von Euw, K. Tschuemperlin and H. Leuenberger et al., 2003. Concentrate feeding strategy in lactating dairy cows: Metabolic and endocrine changes with emphasis on leptin. J. Dairy Sci., 86: 1690-1706. DOI: 10.3168/jds.S0022-0302 (03)73755-2

Santos, J.E.P., J.T. Huber, C.B. Theurer, C.B. Nussio and L.G. Nussio et al., 2000. Effects of grain processing and bovine somatotropin on metabolism and ovarian activity of dairy cows during early lactation. J. Dairy Sci., 83: 1004-1015. DOI: 10.3168/jds.S0022-0302 (00)74965-4

Studer, V.A., R.R. Grummer, S.J. Bertics and C.K. Reynolds, 1993. Effect of prepartum propylene glycol administration on periparturient fatty liver in dairy cows. J. Dairy Sci., 76: 2931-2939. DOI:10.3168/jds.S0022-0302 (93)77633-X
Van Den Top, A.M., M.J.H. Geelen, T. Wensing, G.H. Wentink and A.T. Vant Klooster et al., 1995. Higher postpartum hepatic triacylglycerol concentrations in dairy cows free rather than restricted access to feed during the dry period are associated with lower activities of hepatic glycerolphosphate acyltransferase. J. Nutr., 126: 76-85. http://jn.nutrition.org/content/126/1/76

Wadhwa, D., N.F.G. Beck, L.P. Borgida, M.S. Dhanoa and R.J. Dewhurst, 2001. Development of a simple in vitro assay for estimating net rumen acid load from diet ingredients. J. Dairy Sci., 84: 1109-1117. DOI: $10.3168 /$ jds.S0022-0302 (01)74571-7

Yang, Y.T. and R.L. Baldwin, 1973. Lipolysis in isolated cow adipose cells. J. Dairy Sci., 56: 366374. DOI: $10.3168 /$ jds.S0022-0302 (73)85179-3 